\title{
Pengaruh Metode Role Playing Terhadap Pembelajaran Resolusi Konflik di Sekolah Dasar
}

\author{
Sinta Maria Dewi \\ FKIP Universitas Buana Perjuangan, Jl. HS.Ronggo Waluyo, Karawang, Jawa Barat \\ Corresponding author's : sintamaria@ubpkarawang.ac.id
}

\section{The Effect of Role Playing Method on Conflict Resolution Learning in Elementary School}

\begin{tabular}{l}
\hline Kata Kunci \\
\hline Metode Role Playing, \\
Pembelajaran Resolusi \\
Konflik
\end{tabular}

Keywords:

Role Playing Method, Conflict Resolution Learning

\begin{abstract}
Abstrak
Penelitian ini bertujuan untuk mengetahui Pengaruh Metode Role Playing terhadap Pembelajaran Resolusi Konflik di Sekolah Dasar. Metode penelitian yang di gunakan adalah metode kuasi eksperimen. Pengumpulan data melalui pretest dan posttes. Berdasarkan hasil penelitian dan analisis data rata-rata pretest kelas eksperimen sebesar 49,4 dan kelas kontrol sebesar 48,25. Setelah diberikan perlakuan dan melakukan postest bahwa hasil eksperimen sebesar 68,1 lebih tinggi dibandingkan dengan nilai rata-rata kelas kontrol sebesar 54,75. Perhitungan hipotesis dengan menggunakan Uji-t yakni Uji paired sampel $T$ test dan diperoleh pada taraf signifikan 0.05 menunjukan bahwa nilai probabilitas (signifikansi) adalah 0.00 . karena nilai signifikansi, maka $\mathrm{H}_{\circ}$ di tolak. Hal ini membuktikan bahwa penggunaan model pembelajaran Role Playing berpengaruh terhadap keterampilan resolusi konflik siswa kelas V SDN Anggadita V.Dari hasil penelitian ini peneliti berharap dapat memberikan kontribusi dan manfaat bagi semua pihak-pihak yang terkait, terutama pihak sekolah dalam rangka memberikan pembelajaran resolusi konflik kepada anak sekolah dasar sehingga siswa memiliki keterampilan dalam memecahkan masalah sehingga dapat bermanfaat bagi kehidupan sehari-hari dan masa depannya.
\end{abstract}

\begin{abstract}
:
This study aims to determine the effect of the role playing method on learning conflict resolution in elementary schools. The research method used is a quasi-experimental method. Data collection through pretest and posttest. Based on the results of research and data analysis, the pretest average experimental class was 49.4 and the control class was 48.25. After being given treatment and doing a posttest that the experimental results were 68.1 higher than the control class average value of 54.75. The calculation of the hypothesis using $t$-test, namely the paired sample $T$ test and obtained at a significant level of 0.05 indicates that the probability value (significance) is 0.00 . because of the significance value, Ho is rejected. This proves that the use of the role playing learning model affects the conflict resolution skills of fourth grade students of SDN Anggadita V. From the results of this study the researcher hopes to contribute and benefit to all parties involved, especially the school in order to provide conflict resolution learning to elementary school children so that students have skills in solving problems so that it can be beneficial for their daily life and their future.
\end{abstract}

\section{PENDAHULUAN}

Konflik merupakan suatu yang alamiah terjadi karena tidak terjadinya interaksi sosial yang harmonis. Maftuh (2010) menyatakan bahwa konflik muncul menjadi sebuah bentuk interaksi sosial dimana masing-masing pihak ingin saling mengalahkan. Konflik terjadi pada 
semua kalangan tidak terkecuali anak usia sekolah dasar. Jumat 20 Juli 2018 anak lelaki kelas enam SD (12 tahun) di Kabupaten Garut, Jawa Barat, tewas usai berkelahi dengan teman sekelasnya. Pertikaian tersebut dipicu masalah buku yang hilang dan buku tersebut ditemukan di bawah meja korban (News.Detik.Com 2018). Wiyanto

Genting (2018) mengungkapkan di Kabupaten Bandung seorang siswa SD berinisial AM (11 tahun) tewas berkelahi dengan siswa lain berinisial AR Sabtu 25 November 2017. Perkelahian terjadi pada saat mereka akan bermain sepakbola. Tiba-tiba AR mengajak berkelahi dengan mengucapkan kata-kata "Maneh wani gelut jeung urang (kamu berani berantem sama saya)" dan terjadilah perkelahian. Diyakini masih banyak kasus-kasus konflik yang terjadi pada siswa SD. Kejadian semacam ini perlu penanganan yang serius supaya tidak banyak terulang lagi.

Beberapa upaya sudah dilakukan untuk menangani konflik dikalangan siswa. Menurut Ramadhani \& Rahmasari (2011) penerapan outbound training efektif dalam meningkatkan kemampuan resolusi konflik interpersonal remaja. Penerapan layanan resolusi konflik dapat digunakan untuk menangani konflik interpersonal siswa kelas X-8 SMA (Safitri 2014). Penelitian yang dilakukan oleh Juniarti (2014) menunjukan bahwa setiap siswa memiliki gambaran dinamika psikologis yang berbeda-beda ketika menghadapi konflik sehingga berpengaruh terhadap cara siswa dalam menyelesaikan konflik tersebut. Beberapa upaya tersebut dilakukan tingkat SMA sederajat. Masih belum banyak upaya yang dilakukan untuk menangani konflik di tingkat SD. Salah satu altrnatif penanganan pencegahan konflik yaitu adanya pembelajar an resolusi konflik di SD dengan metode pembelajaran role playing.

Menurut Huda (2013) esensi role playing adalah keterlibatan partisipan dan peneliti dalam situasi permasalahan dan adanya keinginan untuk memunculkan resolusi damai serta memahami apa yang dihasilkan dari keterlibatan langsung ini. Metode pembelajaran role playing merupakan suatu aktivitas yang dramatik, biasanya ditampilkan oleh sekelompok kecil siswa, bertujuan mengeskploitasi beberapa masalah yang ditemukan untuk melengkapi partisipan dan pengamat dengan pengalaman belajar yang nantinya dapat meningkatkan pemahaman mereka (Sharan and Yael, 1976). Beberapa penelitian menunjukan bahwa role playing efektif digunakan dalam pembelajaran. Baroroh (2011) menyatakan bahwa role playing dapat meningkatkan nilai-nilai karakter mahasiswa yang dapat dilihat dari indikator disiplin, kerja keras, kreatif, dan kemampuan komunikasi. Senada dengan Barohah, penerapan metode bermain peran dapat meningkatkan karakter (jujur, kerja sama, tanggung jawab) dan hasil belajar siswa (Perdani 2013), meningkatkan keterampilan sosial dan keterampilan berbicara anak (Pratiwi 2018) dan meningkatkan nilai-nilai kepedulian dan kerja sama antarmahasiswa (Pranowo 2013).

Dari hasil beberapa penelitian di atas menunjukkan bahwasannya Role Playing dapat dijadikan sebagai media dalam penanaman nilai dengan melibatkan siswa pada pemodelan situasi permasalahan yang mendorong lahirnya pemahaman dan alternative resolusi permasalahan. Maka dari itu, penulis akan meneliti mengenai "Pengaruh Metode Role Playing terhadap Pembelajaran Resolusi Konflik di Sekolah Dasar". (Penelitian Eksperimen Kelas V SDN Anggadita V Kecamatan Klari Kabupaten Karawang).

\section{METODE PENELITIAN}

Metode yang digunakan pada penelitian ini adalah metode penelitian kuasi eksperimen. Desain yang digunakan dalam penelitian ini adalah Nonequivalent Control Group Design yang subjeknya tidak dikelompokkan secara acak. Oleh karenanya peneliti berusaha agar kelompokkelompok yang dibandingkan tersebut seserupa mungkin. Desain penelitian ini menggunakan dua kelompok subjek, satu diberi perlakuan eksperimental dan yang lain memperoleh perlakuan biasa. Ruseffendi 2010: 53) mengatakan, "pada desain eksperimen ini ada pretes, perlakuan yang berbeda, dan ada postes; dimana banyaknya kelompok bisa diperbanyak lebih dari dua buah". Diagram eksperimennya dapat digambarkan sebagai berikut:

$$
\begin{gathered}
0 \times 0 \\
0
\end{gathered}
$$

Keterangan:

$0 \quad$ : Pretest dan Posttest pada kelas eksperimen dan kontrol

X : Perlakuan Resolusi Konflik melalui Metode Role Playing

: Subjek tidak dikelompokkan secara acak

Ruseffendi dalam (Pratiwi 2019:53) 
Lokasi penelitian akan dilaksanakan di SDN Anggadita $\vee$ yang berlokasi di Jln Raya Klari, Dsn Rumambe Desa Anggadita Klari-Karawang, dengan waktu penelitian mulai dari bulan Februari sampai bulan Mei tahun pelajaran 2020/2021. Teknik analisis data yang digunakan dalam penelitan ini terdapat beberapa langkah. Pertama, dilakukan pengolahan data pretest dan posttest. Pengolahan data dilakukan untuk mencari rata-rata, median, modus, simpangan baku, nilai maksimum, nilai minimum. Selanjutnya distribusi frekuensi divisualisasikan melalui tabel histogram. Kedua, dilakukan pengujian analisis yaitu uji normalitas dan pengujian homogenitas. Ketiga, dilakukan pengujian hipotesis dengan menggunakan uji-t.

\section{HASIL DAN PEMBAHASAN}

Penelitian ini dilakukan kepada siswa kelas V SDN Anggadita V, untuk membuktikan resolusi konflik IPS siswa pada mata pelajaran IPS. Hasil penelitian yang akan dibahas lebih lanjut mengenai deskripsi data dan dipaparkan lebih lengkap mengenai resolusi konflik siswa pada mata pelajaran IPS. Data yang diperoleh oleh peneliti berupa data kuantitatif.

Tabel 1. Rangkuman Data Statistik Nilai Pretest Resolusi Konflik IPS

Kelas Eksperimen dan Kelas Kontrol

\begin{tabular}{l|c|c|c|c|c|c|c}
\hline Kelas & Mean & Median & Modus & Varians & $\begin{array}{c}\text { Standar } \\
\text { Deviasi }\end{array}$ & $\begin{array}{c}\text { Nilai } \\
\text { Min }\end{array}$ & $\begin{array}{c}\text { Nilai } \\
\text { Mak }\end{array}$ \\
\hline Eksperimen & 49,4 & 50 & 50 & 11,73 & 3,42 & 43 & 57 \\
\hline Kontrol & 48,25 & 48 & 48 & 9,36 & 3,60 & 42 & 55 \\
\hline
\end{tabular}

Adapun rangkuman hasil pengolahan data peningkatan pretest-postest kelas eksperimen tersebut dapat dilihat pada tabel berikut :

Tabel 2. Data peningkatan pretest-posttest kelas eksperimen

\begin{tabular}{|c|c|c|c|c|}
\hline No & Nama & Pretest & Posttest & N Gain \\
\hline 1 & $\mathrm{R} 1$ & 45 & 76 & 1 \\
\hline 2 & $\mathrm{R} 2$ & 43 & 68 & 0,81 \\
\hline 3 & R3 & 57 & 70 & 0,68 \\
\hline 4 & R4 & 50 & 68 & 0,84 \\
\hline 5 & R5 & 51 & 63 & 0,88 \\
\hline 6 & R6 & 50 & 69 & 0,76 \\
\hline 7 & $\mathrm{R} 7$ & 54 & 69 & 0,68 \\
\hline 8 & $\mathrm{R} 8$ & 51 & 66 & 0,68 \\
\hline 9 & R9 & 49 & 67 & 0,74 \\
\hline 10 & R10 & 45 & 67 & 0,7 \\
\hline 11 & R11 & 46 & 68 & 0,8 \\
\hline 12 & R12 & 53 & 69 & 0,69 \\
\hline 13 & R13 & 52 & 67 & 0,83 \\
\hline 14 & R14 & 50 & 67 & 0,65 \\
\hline 15 & R15 & 48 & 66 & 0,71 \\
\hline 16 & R16 & 51 & 70 & 0,61 \\
\hline 17 & R17 & 45 & 68 & 0,8 \\
\hline 18 & R18 & 50 & 69 & 0,88 \\
\hline 19 & R19 & 50 & 66 & 0,69 \\
\hline 20 & R20 & 48 & 69 & 0,92 \\
\hline \multicolumn{2}{|c|}{ Jumlah } & & & 15,35 \\
\hline \multicolumn{2}{|c|}{ Rata-rata } & & & 0,77 \\
\hline
\end{tabular}


Berdasarkam tabel data peningkatan pretest-posttest kelas eksperimen menunjukkan bahwa nilai $\mathrm{N}$-Gain kelas eksperimen adalah $0,77<\mathrm{d} \leq 0.8$, maka efeknya adalah sedang. Dapat ditarik kesimpulan, resolusi konflik siswa di kelas eksperimen memiliki peningkatan $0.77<\mathrm{d} \leq$ 0.8 , artinya terdapat peningkatan resolusi konflik pretest-posttest di kelas eksperimen adalah sedang.

Tabel 3. Data peningkatan pretest-posttest kelas kontrol

\begin{tabular}{|c|c|c|c|c|}
\hline No & Nama & Pretets & Posttest & N Gain \\
\hline 1 & $\mathrm{R} 1$ & 47 & 57 & 0,34 \\
\hline 2 & $\mathrm{R} 2$ & 42 & 51 & 0,26 \\
\hline 3 & R3 & 55 & 57 & 0,09 \\
\hline 4 & R4 & 52 & 61 & 0,16 \\
\hline 5 & R5 & 48 & 56 & 0,2 \\
\hline 6 & R6 & 46 & 51 & 0,33 \\
\hline 7 & R7 & 49 & 58 & 0,36 \\
\hline 8 & $\mathrm{R} 8$ & 51 & 56 & 0,2 \\
\hline 9 & R9 & 51 & 58 & 0,16 \\
\hline 10 & R10 & 49 & 56 & 0,25 \\
\hline 11 & R11 & 49 & 57 & 0,14 \\
\hline 12 & R12 & 50 & 53 & 0,11 \\
\hline 13 & R13 & 46 & 51 & 0,16 \\
\hline 14 & R14 & 45 & 52 & 0,22 \\
\hline 15 & R15 & 48 & 60 & 0,42 \\
\hline 16 & R16 & 47 & 57 & 0,34 \\
\hline 17 & R17 & 51 & 55 & 0,2 \\
\hline 18 & R18 & 43 & 48 & 0,21 \\
\hline 19 & R19 & 48 & 50 & 0,07 \\
\hline 20 & R20 & 48 & 51 & 0,14 \\
\hline \multicolumn{2}{|c|}{ Jumlah } & & & 4,36 \\
\hline \multicolumn{2}{|c|}{ Rata-rata } & & & 0,22 \\
\hline
\end{tabular}

Berdasarkan tabel data peningkatan pretest-posttest kelas kontrol menunjukkan bahwa nilai $\mathrm{N}$-Gain kelas kontrol adalah $0.22<\mathrm{d} \leq 0.8$, maka efeknya adalah sedang. Dapat ditarik kesimpulan, resolusi konflik di kelas kontrol memiliki peningkatan $0.22<\mathrm{d} \leq 0.8$, artinya terdapat peningkatan resolusi konflik pretest-posttest di kelas eksperimen adalah sedang.

Tabel 4. Uji Normalitas Pretest Kelas Eksperimen dan Kelas Kontrol

\section{Tests of Normality}

Kolmogorov-Smirnov ${ }^{\mathrm{a}}$

\begin{tabular}{ll|r|r|r|r|r|r} 
& kelas & Statistic & \multicolumn{1}{c|}{ Df } & \multicolumn{1}{c}{ Sig. } & Statistic & \multicolumn{1}{c}{ df } & \multicolumn{1}{c}{ Sig. } \\
\hline Resolusi & eksperimen & .170 & 20 & .134 & .963 & 20 & .600 \\
\cline { 2 - 10 } Konflik & kontrol & .117 & 20 & $.200^{*}$ & .978 & 20 & .907 \\
\hline
\end{tabular}

*. This is a lower bound of the true significance.

a. Lilliefors Significance Correction

Berdasarkan tabel One-Sample Shapiro Wilk Test di atas, menunjukkan bahwa nilai signifikan Pretest pada kelas eksperimen adalah 0,600 dan nilai siginfikan pada kelas kontrol 0,907 . Hal ini membuktikan bahwa kedua nilai baik dari kelas eksperimen maupun kelas kontrol lebih besar dari $\alpha=0,05(0,600>a=0,05$ dan 0,907 $>a=0,05)$, maka data kedua kelas 
berdistribusi normal. Adapun untuk perhitungan uji normal posttest pada kelas eksperimen dan kelas kontrol dapat dilihat pada tabel berikut :

Tabel 5. Uji Normalitas Poettest Kelas Eksperimen dan Kelas Kontrol

\begin{tabular}{l|l} 
Kolmogorov-Smirnov & Shapiro-Wilk
\end{tabular}

\begin{tabular}{llr|r|r|r|r|r} 
& kelas & Statistic & \multicolumn{1}{c|}{ Df } & \multicolumn{1}{c}{ Sig. } & Statistic & \multicolumn{1}{c}{ df } & \multicolumn{1}{l}{ Sig. } \\
\hline $\begin{array}{l}\text { Resolusi } \\
\text { Konflik }\end{array}$ & eksperimen & .259 & 20 & .001 & .926 & 20 & .130 \\
\cline { 2 - 9 } & kontrol & .200 & 20 & .035 & .942 & 20 & .266 \\
\hline
\end{tabular}

a. Lilliefors Significance Correction

Berdasarkan tabel One-Sample Shapiro Wilk Test di atas, menunjukkan bahwa nilai signifikan Posttest pada kelas eksperimen adalah 0,600 dan nilai siginfikan pada kelas kontrol 0,907 . Hal ini membuktikan bahwa kedua nilai baik dari kelas eksperimen maupun kelas kontrol lebih besar dari $a=0,05(0,600>a=0,05$ dan 0,907 $>a=0,05)$, maka data kedua kelas berdistribusi normal.

Setelah melakukan perhitungan uji normalitas dan kedua kelas sampel dinyatakan berdistribusi normal, selanjutnya mencari nilai homogenitas varians Pretest dan posttest pada kelas eksperimen dan kontrol. Perhitungan uji homogenitas menggunakan bantuan SPSS versi 24.00 adapun kriteria pengujian homogenitas adalah sebagai berikut :

1) Jika probabilitas $>0,05$, maka $H_{o}$ diterima, artinya varians dinyatakan homogen

2) Jika probabilitas $<0,05$, maka $H_{o}$ ditolak, artinya varians dinyatakan homogen.

Berdasarkan analisis uji normalitas dengan menggunakan uji Levene's Test diperoleh hasil sebagai berikut :

Tabel 6. Uji Hipotesis Kelas Eksperimen dan Kelas Kontrol

Levene's Test for

Independent Samples Test

\begin{tabular}{|c|c|c|c|c|c|c|c|c|c|c|}
\hline & & $\begin{array}{r}\text { Levene's } \\
\text { Equal } \\
\text { Varia }\end{array}$ & $\begin{array}{l}\text { est for } \\
\text { of } \\
\text { es }\end{array}$ & & & t-test & for Equal & ity of Mea & & \\
\hline & & & & & & Sig. (2- & $\begin{array}{c}\text { Mean } \\
\text { Differen }\end{array}$ & $\begin{array}{c}\text { Std. } \\
\text { Error } \\
\text { Differen }\end{array}$ & $\begin{array}{r}95 \% \text { Con } \\
\text { Interva } \\
\text { Diffe }\end{array}$ & $\begin{array}{l}\text { idence } \\
\text { of the } \\
\text { nce }\end{array}$ \\
\hline & & $\mathrm{F}$ & Sig. & $\mathrm{t}$ & $\mathrm{df}$ & tailed) & ce & ce & Lower & Upper \\
\hline $\begin{array}{l}\text { Resolusi } \\
\text { Konflik }\end{array}$ & $\begin{array}{l}\text { Equal variances } \\
\text { assumed }\end{array}$ & .199 & .658 & $\begin{array}{r}17.43 \\
9\end{array}$ & 38 & .000 & .550 & .032 & .486 & .613 \\
\hline & $\begin{array}{l}\text { Equal variances } \\
\text { not assumed }\end{array}$ & & & $\begin{array}{r}17.43 \\
9\end{array}$ & $\begin{array}{r}37.90 \\
7\end{array}$ & . 000 & .550 & .032 & .486 & .613 \\
\hline
\end{tabular}

Berdasarkan hasil uji hipotesis pada tabel di atas diperoleh nilai $F$ yang mengansumsikan bahwa kedua varians sama adalah dengan nilai $\mathrm{t}=17,439 . \mathrm{A}=0,05$ diperoleh sig 0,000 . Karena sig $<0,05$ dengan demikian $H_{o}$ ditolak atau dengan kata lain $H_{o}$ diterima, artinya terdapat perbedaan yang signifikan antara resolusi konflik yang menggunakan model pembelajaran role playing dengan yang menggunakan metode ceramah. Hal ini menunjukkan bahwa penggunaan model pembelajaran role playing lebih baik dari pada menggunakan metode ceramah.

\section{KESIMPULAN}

Berdasarkan hasil penelitian dan analisis data, maka dapat disimpulkan bahwa penggunaan model pembelajaran Role Playing berpengaruh terhadap resolusi konflik siswa kelas V di SDN Anggadita V. Berdasarkan hasil penelitian dan analisis data rata-rata pretest kelas eksperimen sebesar 49,4 dan kelas kontrol sebesar 48,25. Setelah diberikan perlakuan dan melakukan postest bahwa hasil eksperimen sebesar 68,1 lebih tinggi dibandingkan dengan nilai rata-rata kelas kontrol sebesar 54,75. Perhitungan hipotesis dengan menggunakan Uji-t yakni Uji paired sampel $T$ test dan diperoleh pada taraf signifikan 0.05 menunjukan bahwa nilai probabilitas (signifikansi) adalah 0.00 . karena nilai signifikansi, maka $H_{0}$ di tolak. Hal ini membuktikan bahwa penggunaan model pembelajaran Role Playing berpengaruh terhadap keterampilan resolusi konflik siswa kelas V SDN Anggadita V. 


\section{DAFTAR PUSTAKA}

Baroroh, K. (2011). Upaya meningkatkan nilai-nilai karakter peserta didik melalui penerapan metode role playing. Jurnal Ekonomi dan pendidikan, 8(2).

Ginting, H., \& Muazzul, M. (2018). Peranan Kepolisian dalam Penerapan Restorative Justice terhadap Pelaku Tindak Pidana Pengeroyokan yang Dilakukan oleh Anak dan Orang Dewasa. Jurnal Ilmiah Penegakan Hukum, 5(1), 32-40.

Huda, K. M. K., Banu, M. S. A., Tuteja, R., \& Tuteja, N. (2013). Global calcium transducer Ptype Ca2+-ATPases open new avenues for agriculture by regulating stress signalling. Journal of experimental botany, 64(11), 3099-3109.

Juniarti, R. D. (2014). Pengembangan media mobile learning dengan aplikasi schoology pada pembelajaran geografi materi hidrosfer kelas x SMA negeri 1 karanganyar.

Maftuh, B. (2010). Memperkuat Peran IPS dalam Membelajarkan Keterampilan Sosial dan Resolusi http://file.upi.edu/Direktori/PIDATO/3._PIDATO_PENGUKUHAN_BUNYAMIN.pdf

News.detik.com. (2018). Kesal Jarang Diajak Main, Motif Teman Bunuh Bocah SD di Banjar. https: / / news.detik.com/berita-jawa-barat/d-4363688/kesal-jarang-diajak-mainmotif-teman-bunuh-bocah-sd-di-banjar

Perdani, P. A. (2013). Peningkatan keterampilan sosial melalui metode bermain permainan tradisional pada anak TK B. Jurnal Pendidikan Usia Dini, 7(2), 234-250.

Pranowo, D. J. (2013). Implementasi Pendidikan Karakter Kepedulian dan Kerja Sama pada Mata Kuliah Keterampilan Berbicara Bahasa Prancis dengan Metode Bermain Peran. Jurnal Pendidikan Karakter, 2(2).

Pratiwi, I. A., Ardianti, S. D., \& Kanzunnudin, M. (2018). Peningkatan kemampuan kerjasama melalui model project based learning (PjBL) berbantuan metode edutainment pada mata pelajaran ilmu pengetahuan sosial. Refleksi Edukatika: Jurnal Ilmiah Kependidikan, 8(2).

PRATIWI, Y. (2019). PENERAPAN MODEL PROBLEM CENTERED LEARNING (PCL) UNTUK MENINGKATKAN KEMAMPUAN PEMECAHAN MASALAH MATEMATIS DAN SELF-AWARENESS SISWA SMP (Doctoral dissertation, FKIP UNPAS).

Rahmasari, H. S. R. dan D. (2011). Efektifitas Penerapan Outbound Training Dalam Interpersonal Pada Remaja. Jurnal Psikologi: Teori \& Terapan, 2, 1-10. https://journal.unesa.ac.id/index.php/jptt/article/view/1851/1257

Ramadhani, H. S., \& Rahmasari, D. (2011). Efektifitas Penerapan Outbound Training dalam Meningkatkan Kemampuan Resolusi Konflik Interpersonal Pada Remaja. Jurnal Psikologi Teori dan Terapan, 2(1), 1-10.

Safitri, I., Konseling, B., Pendidikan, F. I., \& Surabaya, U. N. (2012). Application for Conflict Resolution Services Interpersonal Conflict Class X-8. Jurnal BK Unesa, 4(1), 154-159. 